\title{
Efficient adsorption of heavy metal ions onto diethylamine functionalized calix[4]arene based silica resin
}

\author{
Ranjhan Junejo $^{\mathrm{a}, *}{ }^{\circ}$ Shahabuddin Memon $^{\mathrm{a}}$ |Ismail Murat Palabiyik $^{\mathrm{b}}$
}

aNational Center of Excellence in Analytical Chemistry, University of Sindh, Jamshoro-76080 / Pakistan

${ }^{b}$ Department of Analytical Chemistry, Faculty of Pharmacy, University of Ankara, Ankara, Turkey

\author{
*Corresponding Author: \\ Ranjhan Junejo \\ Email: ranjhanjunejo@yahoo.com \\ Tel.: +923343754295
}

Water might be contaminated by different metal ions, resulting in different water-borne diseases in human and aquatic life. This research study aimed at synthesizing the diethylamine functionalized calix[4] arene based silica (DFCS) resin for the effective removal of heavy metals such as $\mathrm{Cd}^{2+}, \mathrm{Pb}^{2+}$, and $\mathrm{Hg}^{2+}$ from water. The DFCS resin was characterized using the FTIR spectroscopy and SEM techniques. The efficiency of the DFCS resin for the removal of metal ions was evaluated by performing equilibrium studies under the optimized conditions. Moreover, the experimental data were subjected to isotherm models; however, the Freundlich model was best-fit one as compared to the Langmuir model. The energy calculated from the D-R model was $10.3,9.7$ and $9.2 \mathrm{KJ} / \mathrm{mol}$ for $\mathrm{Cd}^{2+}, \mathrm{Pb}^{2+}$, and $\mathrm{Hg}^{2+}$, respectively, suggesting that the ion exchange process is involved. The thermodynamic values revealed that the reaction is spontaneous and exothermic, following the pseudo second-order kinetic model equation.

\section{KEYWORDS}

Calix[4]arene based resin; metal ions; thermodynamic and kinetic modelling.

\section{Introduction}

Toxic metal ions found in industrial effluents, municipal and urban waste water are very harmful to human beings and aquatic life. Development of urbanization and industrialization are major cause for increasing the level of metal ions in waterways $[1,2]$. The toxic metal ions released from the industries and municipal waste water are accumulated into soil [3]. Toxic metal ions present in wastewater are in very trace level, but they have a toxic effect on the living beings due to their non-degradable nature. Once an entrance into the body through water source, they may create dermal irritation, bacterial and viral infections by altering, removing or impairing the enzyme function. They act as an enzyme mimic by targeting the DNA or other biomolecule site and remove essential minerals and inhibit its functioning [4-8]. Such type of harmful actions are the major cause of lung cancer, bladder, kidney failure diseases and irregularity in blood composition $[3,9,10]$. Therefore, due to the hazardous nature of the metal ions at very low level, it is important to remove them from wastewater. In this regard, different methods and techniques have been applied to remove these toxic metal ions; however, the adsorption is the most common and simple technique to remove these toxic metal ions. In adsorption process, many low cost natural and synthetic adsorbents are used such as lignin and chitosan, while in synthetic 
adsorbents crown ethers, cyclodextrins and other polymeric based resins are widely used [11-15].

Nowadays, the third generation compounds of supramolecular chemistry known as calixarenes are also used as adsorbents. The calixarenes are cyclic oligomers containing two rims, which can be modified by different functional groups to bind with neutral or ionic species. Previously, different studies have been carried out on calixarenes application; for example, piperidine based calix[4]arene silica resin has been applied for the removal of reactive blue 19 dye from water [16]. Calix[4]arene tetraester and calix[6]arene hexaester derivatives exhibit significant selectivity toward $\mathrm{Na}^{+}$and $\mathrm{Pb}^{2+}$, respectively $[17,18]$. In the present study, the diethylamine functionalized calix[4]arene based silica resin was synthesized and applied as an adsorbent for the removal of metal ions.

\section{Experimental procedure}

\section{Reagents and chemicals}

The chemicals used in reactions were of analytical grade. Silica gel was purchased from Sigma Aldrich. 4-tert-butylphenol, toluene, formaldehyde used for the synthesis of calix[4]arene were obtained from Sigma Aldrich. Diethylamine and chloroform was purchased from the Merck. All the metal nitrate solutions were prepared with deionized water.

\section{Instrumentation}

Melting points were determined on a Gallenkamp apparatus model (MFB.595. 010M England) in a sealed capillary. The CHNS study was performed to know the elemental composition of $p$-diethlaminomethylcalix[4]arene and DFCS resin by using elemental analyzer (model Flash EA 1112, 20090-Rodano, Milan, Italy). The confirmation and characterization of all the synthesized compounds have also been performed by FTIR spectroscopy (Thermo Nicollet 5700 FT-IR spectrometer) as $\mathrm{KBr}$ pellets. The surface morphology of DFCS resin was performed using the scanning electron microscopic (SEM, model JSM-6380). The $\mathrm{Cd}^{2+}$ and $\mathrm{Pb}^{2+}$ metal ions concentration was determined and confirmed by atomic absorption spectroscopy (Perkin Elmer model Analyst 700; Norwalk, CT, USA), while the concentration of $\mathrm{Hg}^{2+}$ ions was determined by CVAAS method $[19,20]$. The pH meter (wtw 786 meter) was used to measure the $\mathrm{pH}$. Batch adsorption study was performed using A Gallenkamp thermostat automated mechanical shaker (model BKS 305-101, UK).

\section{Synthesis process}

Synthesis of p-diethylaminomethylcalix[4]arene (3)

The compound $\mathbf{1}$ and $\mathbf{2}$ were synthesized by published methods [21-24], while $p$ diethylaminomethylcalix[4]arene (3) given in (scheme 1) has been synthesized by following reported procedure with little modification [24-28]. $1 \mathrm{~g}$ of compound 2 was solubilized in THF with the addition of $0.5 \mathrm{~mL}$ of diethylamine, $0.2 \mathrm{~mL} \mathrm{HCHO}$ and $1 \mathrm{~mL}$ $\mathrm{CH}_{3} \mathrm{COOH}$ into the reaction flask for $4 \mathrm{~h}$ at $0{ }^{\circ} \mathrm{C}$. The reaction has been confirmed by TLC, FTIR, and melting point. The synthesized compound was recrystallized with chloroform and methanol. The off-white $83 \%$ product was obtained. 


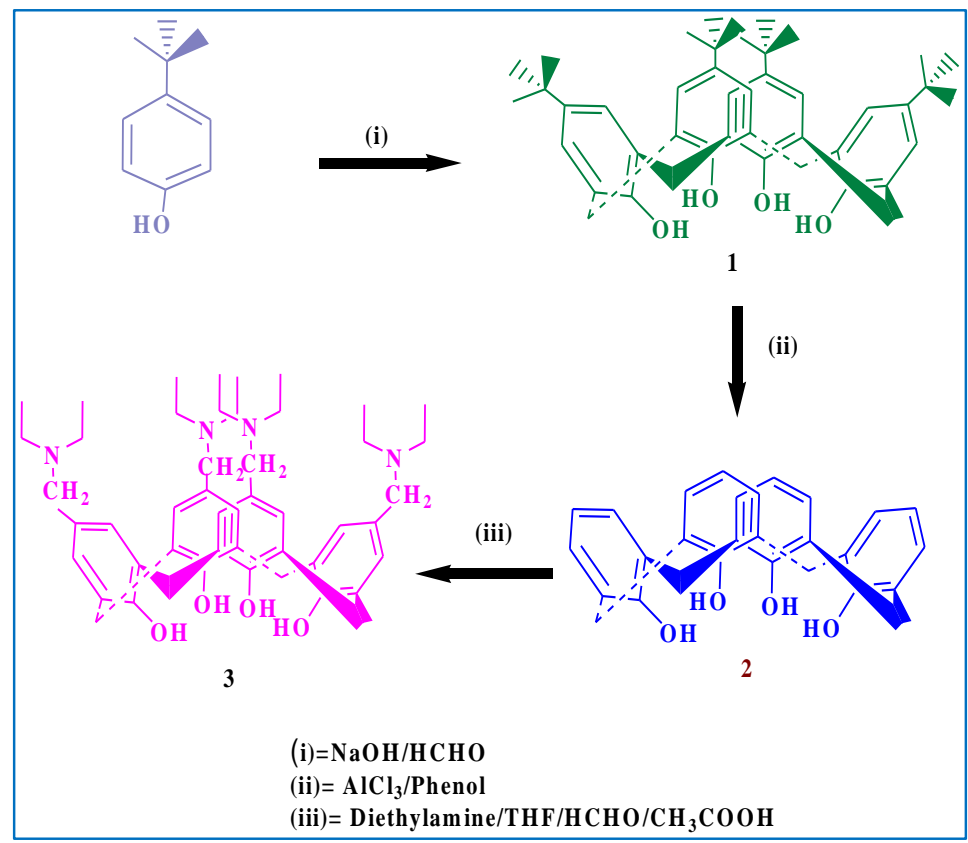

SCHEME 1 Synthesis route of $p$-diethylaminomethylcalix[4]arene (3)

Synthesis of DFCS resin (4)

The DFCS resin (4) was synthesized by the immobilization of compound $\mathbf{3}$ onto silica as given in (Scheme 2). The reaction was performed by following the reported method $[16,29]$ after little modification. Compound 3 ( $2 \mathrm{~g}, 2.6 \mathrm{mmol}$ ) was dissolved in chloroform and added $5 \mathrm{~g}$ of silica already treated with
$\mathrm{SiCl}_{4}$ and heated $36 \mathrm{~h}$ in inert environment. The reaction was monitored by FTIR spectroscopy technique. After confirmation, the surface of DFCS resin was characterized by scanning electron microscopy technique and amount of compound $\mathbf{3}$ attached onto silica surface was measured by gravimetric method, which was found to be $0.0034 \mathrm{mmol.g}^{-1}$.

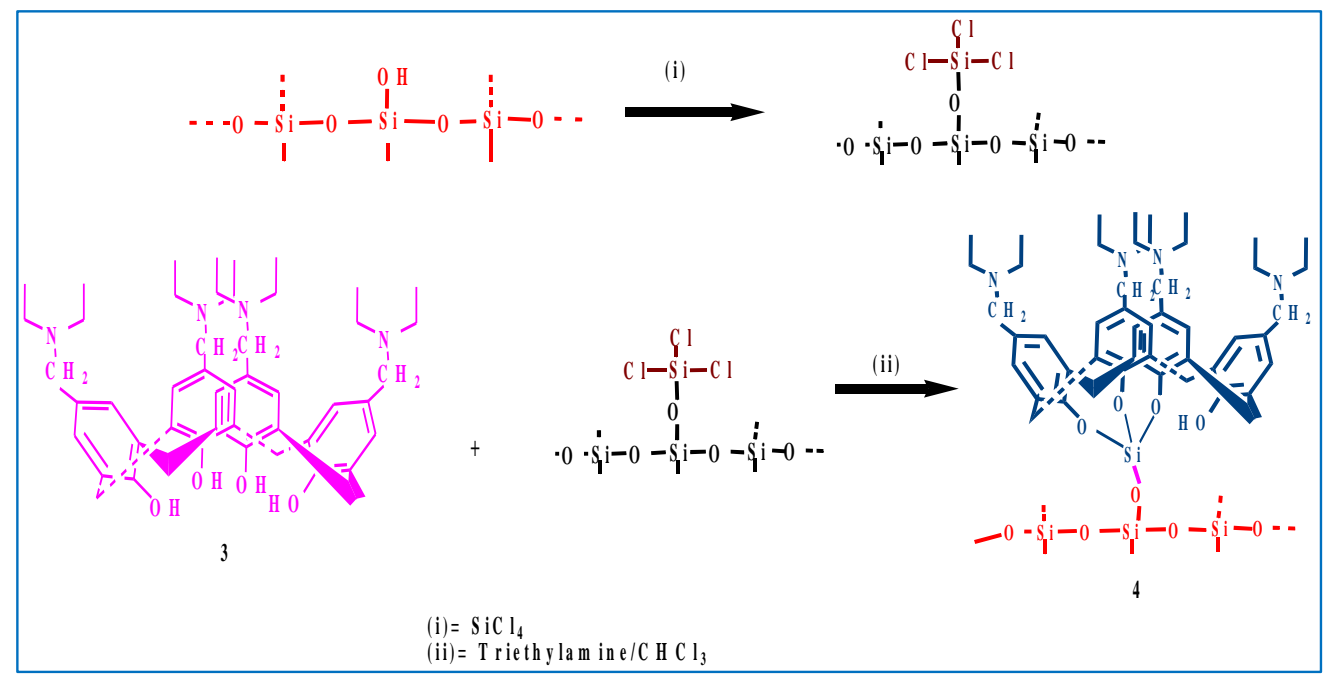

SCHEME 2 Synthesis route of DFCS resin (4)

\section{Adsorption procedure}

The metal ions adsorption ability of the DFCS resin was assessed by batch adsorption experiments under the optimized conditions such as DFCS dosage, pH effect, concentration, time, and temperature effect. The adsorption of metal ions was studied using DFCS resin 
$(0.01,0.025,0.05,0.075,0.1,1.25$, and $1.5 \mathrm{~g})$ in their respective $10 \mathrm{~mL}$ aqueous solution $\left(2.5 \times 10^{-5} \mathrm{M}\right)$. The $\mathrm{pH}$ was adjusted from 3 to 9 using $\mathrm{NaOH}(0.1 \mathrm{M})$ and $\mathrm{HCl}(0.1 \mathrm{M})$. Moreover, the temperature effect was examined at $25,30,35,40,45$, and $50^{\circ} \mathrm{C}$ along with the optimized values of $\mathrm{pH}$ and DFCS resin. During the adsorption isotherm experiments, the initial concentration has been varied from $2.5 \times 10^{-5}$ to $2.5 \times 10^{-7} \mathrm{M}$ and finally all experiments were performed at $\mathrm{pH}$ 7 and $25{ }^{\circ} \mathrm{C}$ with the metal ions solution $\left(2.5 \times 10^{-5} \mathrm{M}\right)$. The kinetic experiments have been performed by taking $0.1 \mathrm{~g}$ of the DFCS resin into Erlenmeyer flask $(50 \mathrm{~mL})$ containing $10 \mathrm{~mL}$ of metal ions solution $\left(2.5 \times 10^{-5} \mathrm{M}\right)$ and at optimized $\mathrm{pH}$ 7. The DFCS resin was filtered off and remaining metal ions concentration have been checked by AAS. All the adsorption experiment data were repeated three times and average values were reported. The \% adsorption and adsorption capacity qe (mmolg-1) of DFCS resin for metal ions were calculated by using the following Equation 1 and 2.

$\%$ adsorption $=\frac{C_{i}-C_{f}}{C_{i}} \times 100$
$q_{e}=\frac{\left(C_{i}-C_{e}\right) V}{m}$

Where $C_{i}$ and $C_{f}$ and $C_{e}(\mathrm{~mol} / \mathrm{L})$ are initial and equilibrium concentration of metal ions, respectively, and $V(\mathrm{~L})$ is the volume of the metal ions and $m$ shows the mass $(\mathrm{g})$ is of DFCS resin.

\section{Results and discussion}

\section{FTIR Study}

All the synthesized compounds were characterized using the FTIR spectroscopy. In Figure 1, the spectrum (a) is of pdiethylaminomethylcalix[4]arene, which shows the characteristic peaks at 3361, 2919, $2663,1606,1434$ and $1251 \mathrm{~cm}^{-1}$ for $\mathrm{OH}, \mathrm{C}-\mathrm{H}$, $\mathrm{C}-\mathrm{C}, \mathrm{C}=\mathrm{C}, \mathrm{C}-\mathrm{O}$ and $\mathrm{C}-\mathrm{N}$ stretching frequencies, respectively, while the peak at $1043 \mathrm{~cm}^{-1}$ is $\mathrm{OH}$ bending frequency. The spectrum (b) has strong absorbance at $1095 \mathrm{~cm}^{-1}$ for $\mathrm{Si}-\mathrm{O}-\mathrm{Si}$ stretching. The peaks at 3454 and $1629 \mathrm{~cm}^{-1}$ are $\mathrm{O}-\mathrm{H}$ stretching and $\mathrm{O}-\mathrm{H}$ bending, respectively. The spectrum (c) is of DFCS resin, which have some new extra bands at 3361,2979 and $1473 \mathrm{~cm}^{-1}$ for $\mathrm{OH}, \mathrm{C}-\mathrm{H}$, and C=C groups of compound $\mathbf{3}$ that has been attached onto silica surface.

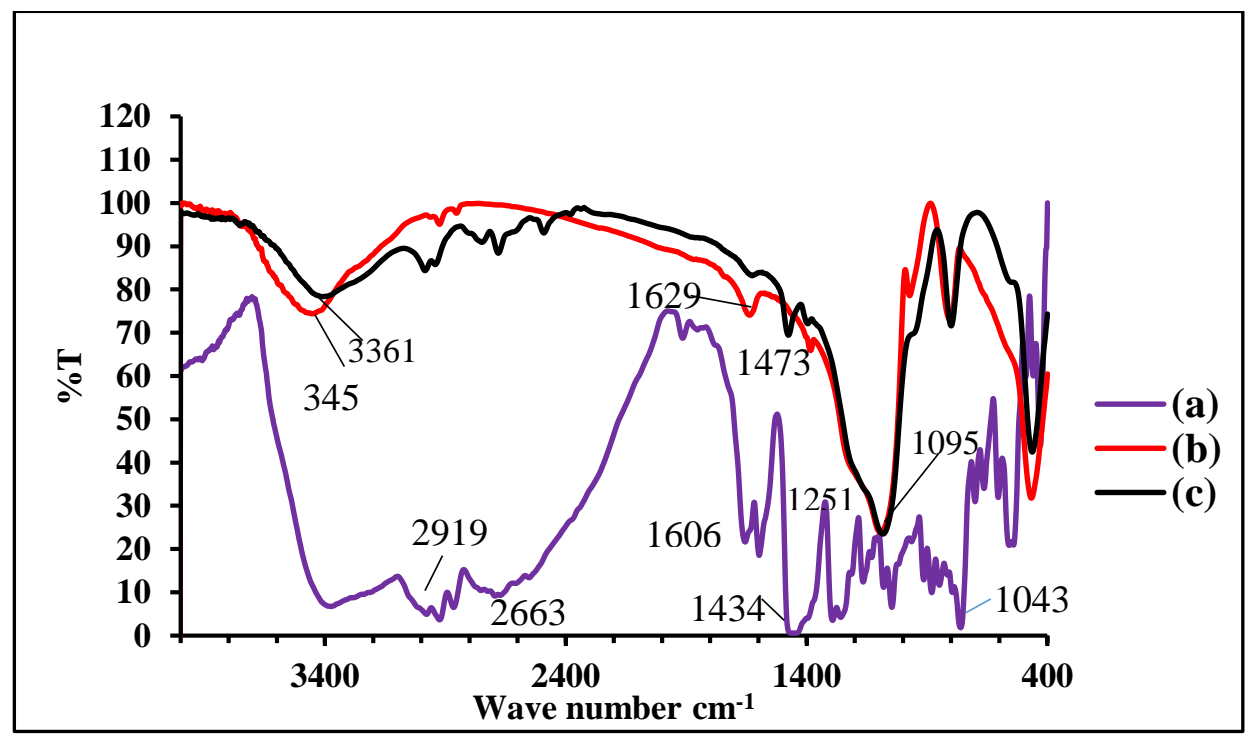

FIGURE1 FTIR Spectrum (a) of p-diethylaminomethylcalix[4]arene (b) silica (c) DFCS resin SEM Analysis 
Surface morphology of the DFCS resin was characterized using the SEM technique. Figure 2 reveals the SEM images of the pure silica and DFCS resin. Figure 2-a shows the pure silica, which is smooth and crystalline; while Figure 2-b demonstrates the DFCS resin, which is rough and amorphous. This clearly shows that the roughness is due to the attachment of compound 3 onto pure silica.

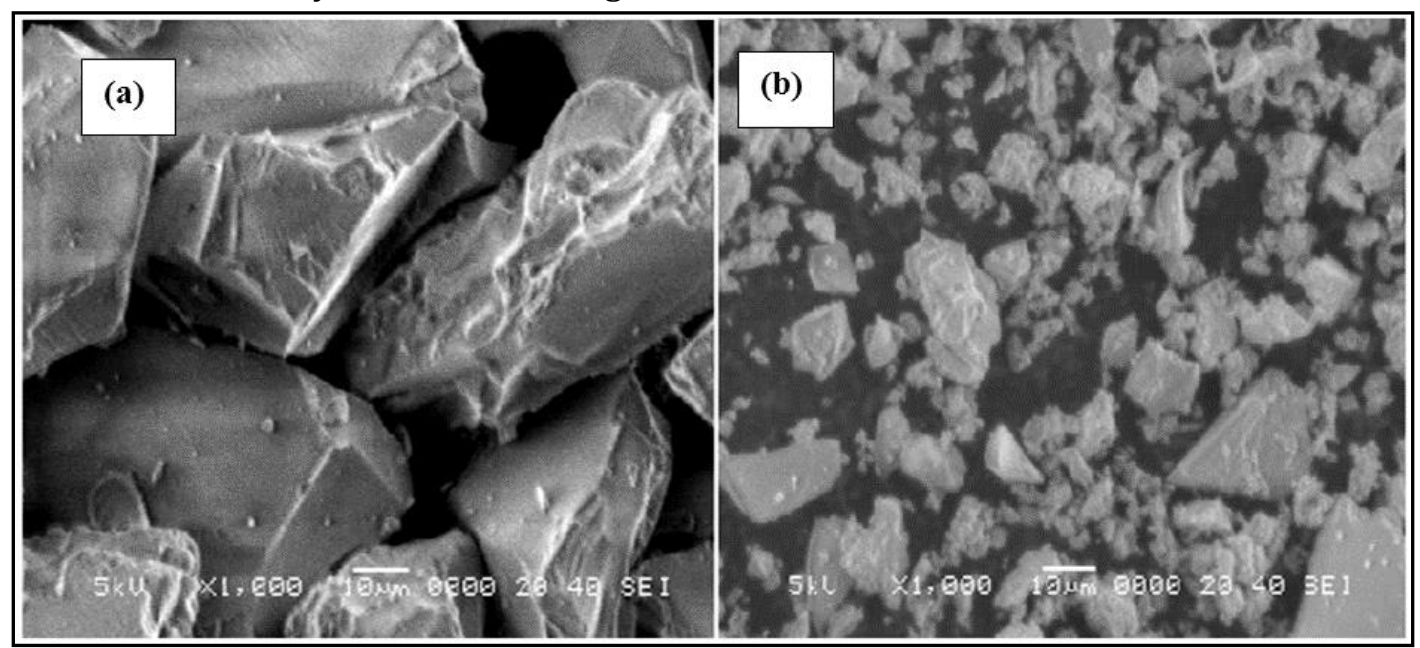

FIGURE 2 SEM images of (a) pure silica and (b) DFCS resin

\section{Metal selectivity}

The DFCS resin has ability to form complexes with different metal ions such as $\mathrm{Cu}^{2+}, \mathrm{Cd}^{2+}$ $\mathrm{Zn}^{2+}, \mathrm{Pb}^{2+}, \mathrm{Ni}^{2+}$, and $\mathrm{Hg}^{2+}$. The DFCS resin has nitrogen moieties containing calixarene compound at its surface, which act as soft coordinate centres for metal ions. The \% adsorption of different metal ions on DFCS resin is demonstrated in Figure 3. As seen in Figure 3, the DFCS resin binds with $\mathrm{Cd}^{2+}, \mathrm{Pb}^{2+}$ and $\mathrm{Hg}^{2+}$ more efficiently as compared to other metal ions may be due to their comparable ionic size and charge.

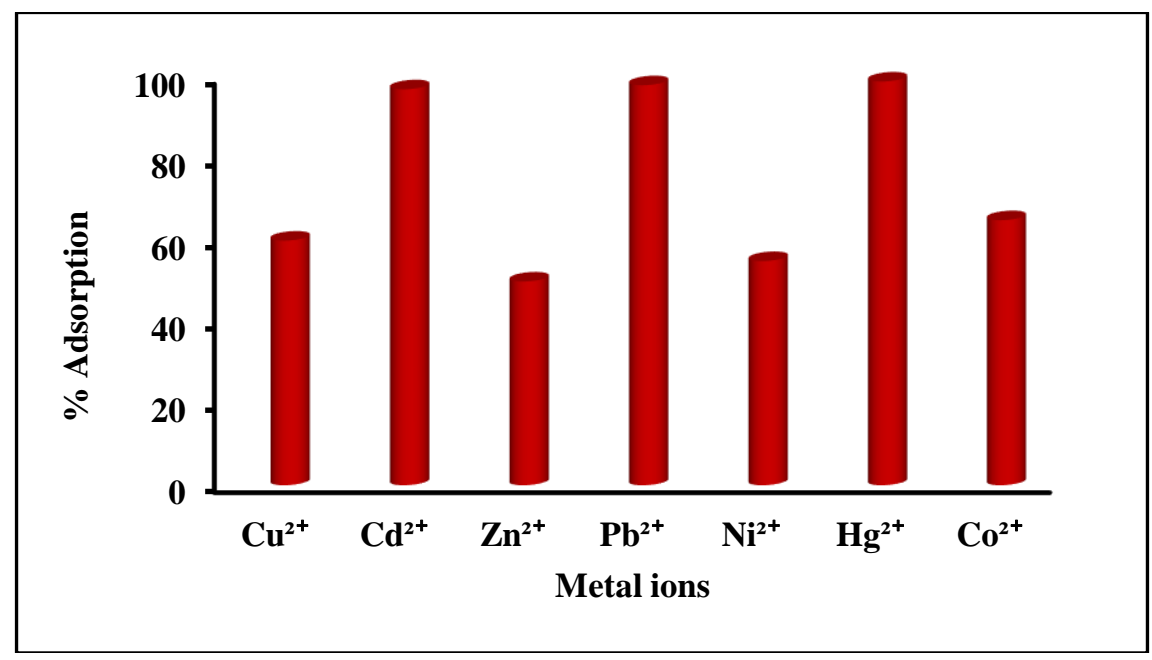

FIGURE 3 The $\%$ adsorption of different metal ions (Conc: $2.5 \times 10^{-5} \mathrm{M}$ )

\section{Adsorbent dosage}

During the adsorption of metal ions; the DFCS resin dosage was optimized, which is one of the most effective parameter to check the binding and adsorption capacity. The graph was plotted between the adsorption percentages versus the DFCS resin 
dosage (Figure 4). The \% adsorption enhanced with increasing the DFCS resin dosage and the maximum 98\% adsorption was achieved at the appropriate dose of $0.1 \mathrm{~g}$, further high doses of DFCS resin show no significant increase in $\%$ adsorption. Therefore, the optimized dosage of the DFCS resin for the removal of metal ions was found to be $0.1 \mathrm{~g}$.

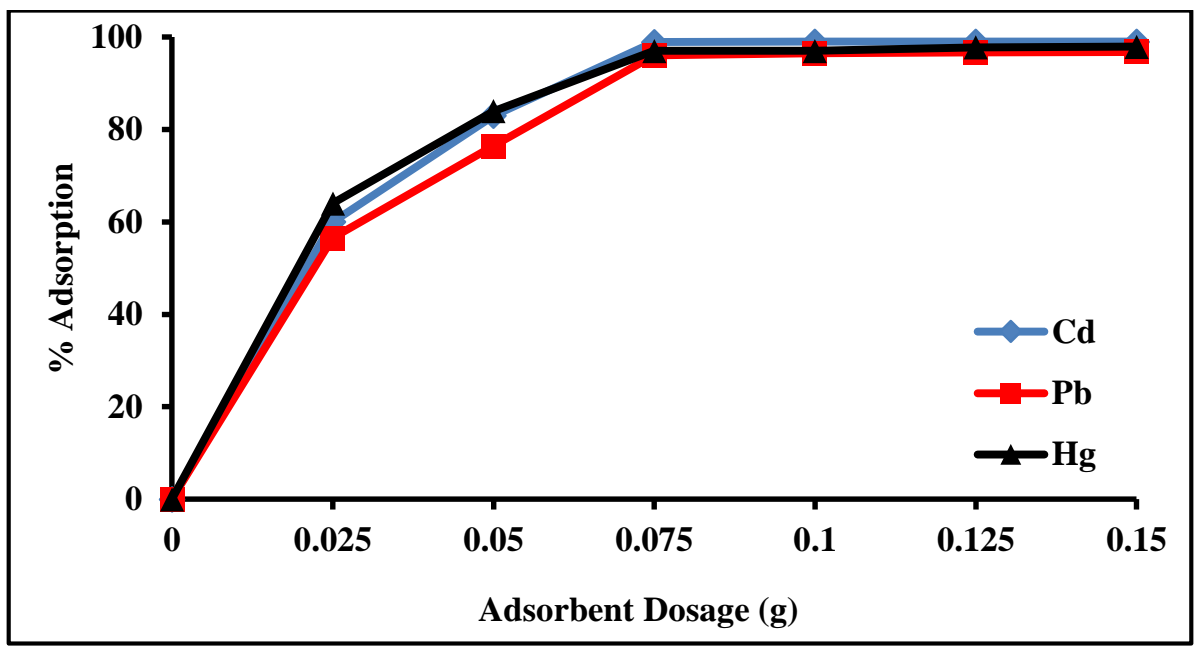

FIGURE 4 The effect of DFCS resin dosage $\left(10 \mathrm{~mL}\right.$ of metal ion solution $2.5 \times 10^{-5} \mathrm{M}, 60 \mathrm{~min}$. contact time)

pH effect

The $\mathrm{pH}$ effect on the adsorption of metal ions by DFCS resin is discussed (Figure 5). The $\mathrm{pH}$ of solution affects the adsorbent surface and the interaction between the adsorbent and metal ions. It has been noted that by increasing the $\mathrm{pH}$ of solution from 3 to 9 , the adsorption percentage increases and $98.9 \%$ adsorption was achieved at $\mathrm{pH} 7$; while the minimum adsorption percentage was observed at low $\mathrm{pH}$ due to the protonation of amine moieties onto DFCS resin surface that reduces the binding sites for the interaction of metal ions. The $\mathrm{pH}$ above 7 shows no significant increase in the adsorption percentage, therefore a neutral condition is favourable for adsorption of metal ions by DFCS resin.

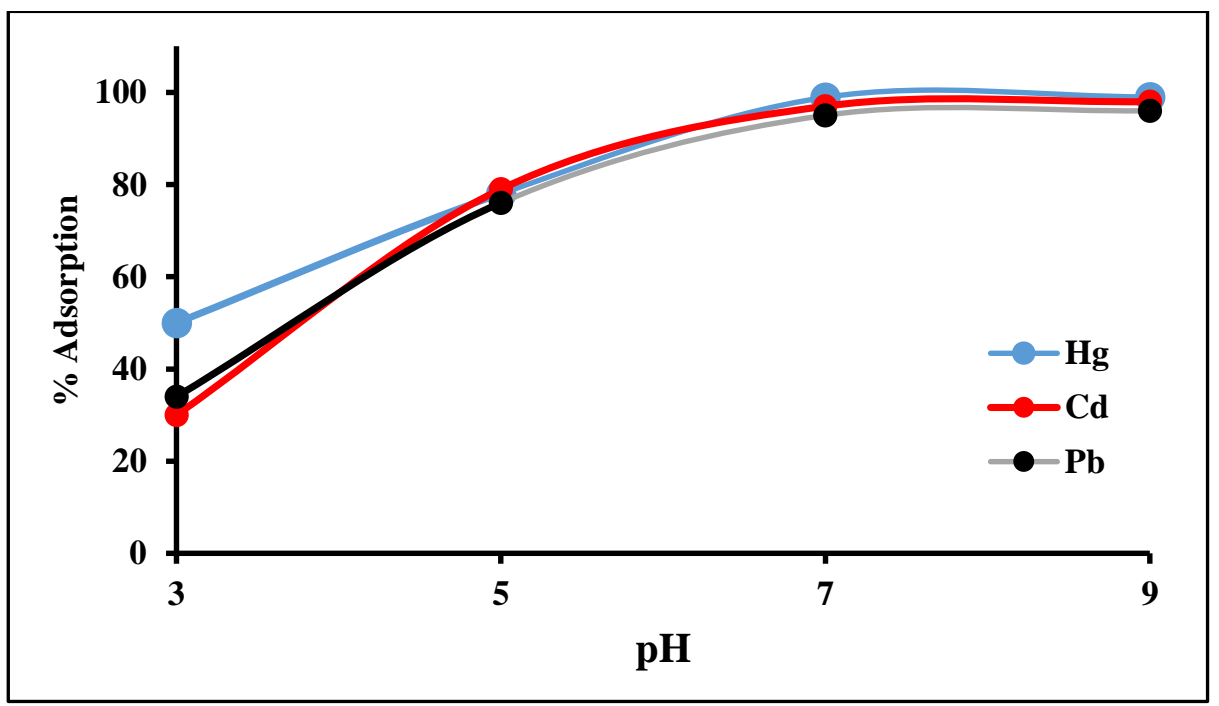

FIGURE 5 The effect of $\mathrm{pH}$ on the adsorption metal ions by DFCS resin 


\section{Isotherm models}

Figure 6 demonstrates the adsorption of the metal ions on DFCS resin as a function of solution concentration $\left(2.5 \times 10^{-7}\right.$ to $2.5 \times 10^{-5}$ $\mathrm{mol} / \mathrm{L})$. By increasing the concentration, the adsorption capacity of the DFCS resin (mmol/g) gradually enhanced and became constant at $2.5 \times 10^{-5} \mathrm{~mol} / \mathrm{L}$, when there was almost no further any adsorption capacity enrichment. This observation indicated that the metal ions bind with the respective sites. Therefore, the maximum adsorption capacity of DFCS resin for $\mathrm{Cd}^{2+}, \mathrm{Pb}^{2+}$ and $\mathrm{Hg}^{2+}$ was found to be $0.42,0.51$ and $0.53 \mathrm{mmol} / \mathrm{g}$, respectively. The analysis of the experimental data is important to describe the adsorbate and adsorbent interactions. Equations 3-5 were used to calculate the Langmuir and Freundlich models.

$\left(\frac{C_{e}}{C_{a d s}}\right)=\left(\frac{1}{Q b}\right)+\left(\frac{C_{e}}{Q}\right)$

$\log C_{a d s}=\log A+\left(\frac{1}{n}\right) \log C_{e}$

$R_{L}=\frac{1}{\left(1+b C_{i}\right)}$

Where $\mathrm{C}_{a d s}$ shows the adsorbed amount of metal ions and $\mathrm{C}_{e}$ is the remaining amount of metal ion at equilibrium, $\mathrm{Q}$ is adsorption capacity during the monolayer formation, and b is Langmuir constant. In Equation 4, A is a constant shows the adsorption capacity, $n$ is the energy or intensity of adsorption, and in Equation $5 R_{\mathrm{L}}$, is an essential characteristic of the Langmuir model.

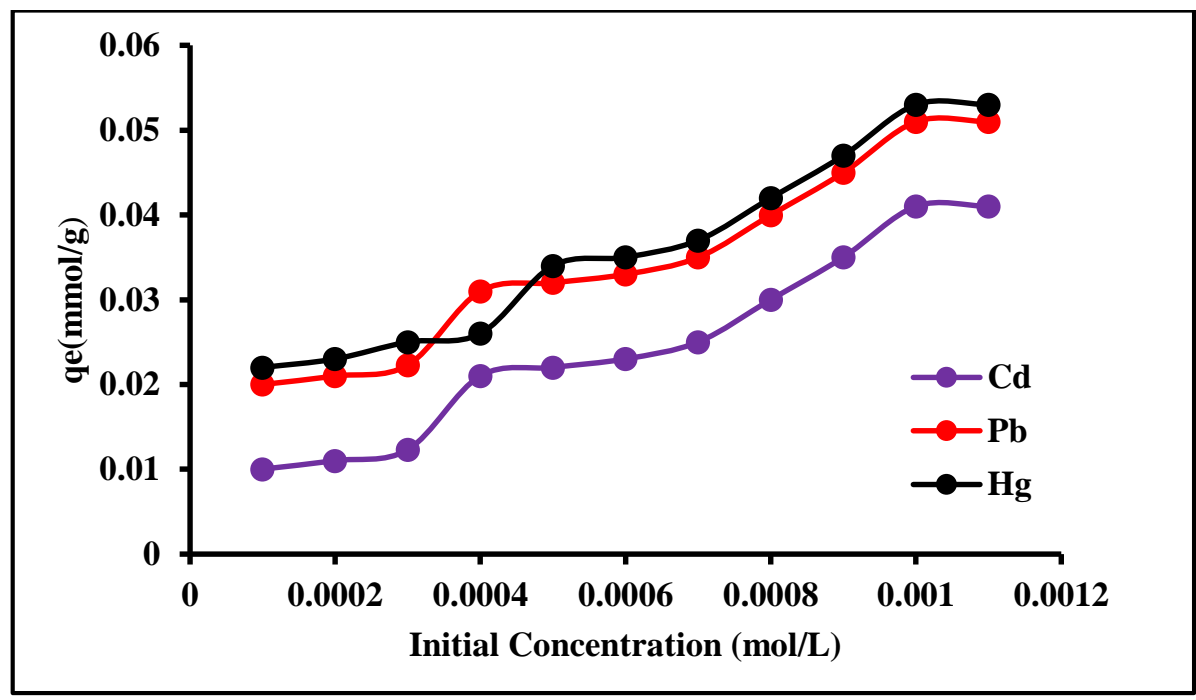

FIGURE 6 Effect of initial concentration on the adsorption of $\mathrm{Cd}^{2+}, \mathrm{Pb}^{2+}$ and $\mathrm{Hg}^{2+}$ on DFCS resin at $0.1 \mathrm{~g}$ of DFCS resin

The Langmuir model was applied and graph was plotted between the Ce vs Cads $\mathrm{mmol} / \mathrm{g}$ (Figure 7) $\mathrm{b}$ and $\mathrm{Q}$ values were obtained from the plot of $\mathrm{C}_{\mathrm{e}} / \mathrm{C}_{\mathrm{ads}}$ mol.g-1 versus
$C_{\mathrm{e}} \mathrm{mol} / \mathrm{L}$ and are shown in Table 1 , which describes that the Langmuir model is not best fit one and does not form monolayer. 


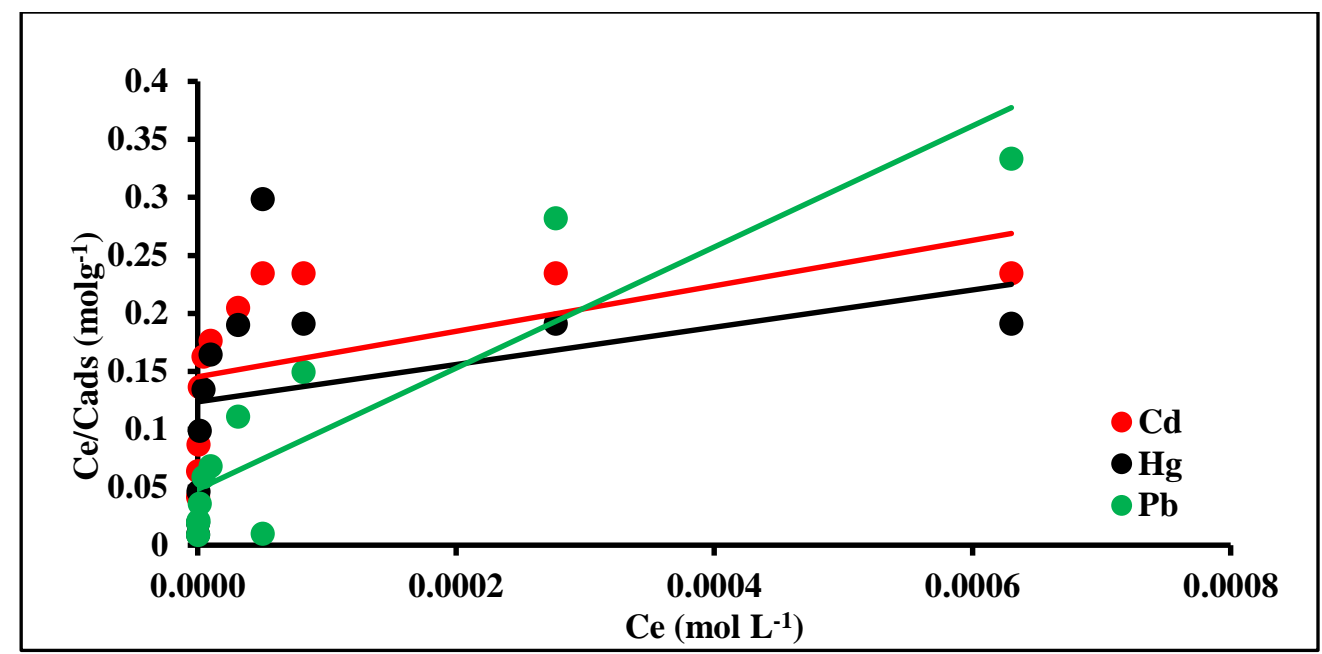

FIGURE 7 Langmuir isotherm (Conc. $2.5 \times 10^{-5}$ to $2.5 \times 10^{-7} \mathrm{~mol} / \mathrm{L}$ ) $0.1 \mathrm{~g}$ of DFCS resin $10 \mathrm{~mL}$ of metal solution at $25^{\circ} \mathrm{C}$

TABLE 1 Langmuir isotherm parameters

\begin{tabular}{ccccc}
\hline Metals & $\mathbf{Q}(\mathbf{m o l} / \mathbf{g})$ & $\mathbf{b}$ & $\mathbf{R}_{\boldsymbol{L}}$ & $\mathbf{R}^{\mathbf{2}}$ \\
\hline $\mathbf{C d}^{\mathbf{2 +}}$ & 2.30 & 10.7 & $0.94-0.99$ & 0.811 \\
$\mathbf{P b}^{\mathbf{2 +}}$ & 6.96 & 10.2 & $0.91-0.99$ & 0.782 \\
$\mathbf{H g}^{2+}$ & 2.41 & 10.1 & $0.33-0.99$ & 0.724 \\
\hline
\end{tabular}

The adsorption on the surface as multilayer formation indicates the validation of Freundlich isotherm model. By applying Equation 4, the values of $\mathrm{A}$ and $\mathrm{n}$ can be obtained from the $\log \mathrm{C}_{\mathrm{ads}}(\mathrm{mol} / \mathrm{g}$ ) versus $\log$ $C_{\mathrm{e}}(\mathrm{mol} / \mathrm{L})$ (Figure 8). If the sorption intensity value $1>n>10$ the phenomenon is referred to cooperative in nature whereas, if $1<\mathrm{n}<10$ indicates the chemisorption nature. This study reveals that the value of $n$ is $1<\mathrm{n}<10$ for $\mathrm{Cd}^{2+}$, $\mathrm{Pb}^{2+}$ and $\mathrm{Hg}^{2+}$ (Table 2), showing that the chemisorption takes place. Furthermore, the value of $\left(R^{2}\right)$ is higher in Freundlich than in Langmuir (Table 1 and 2), indicating the adsorption follows Freundlich isotherm.

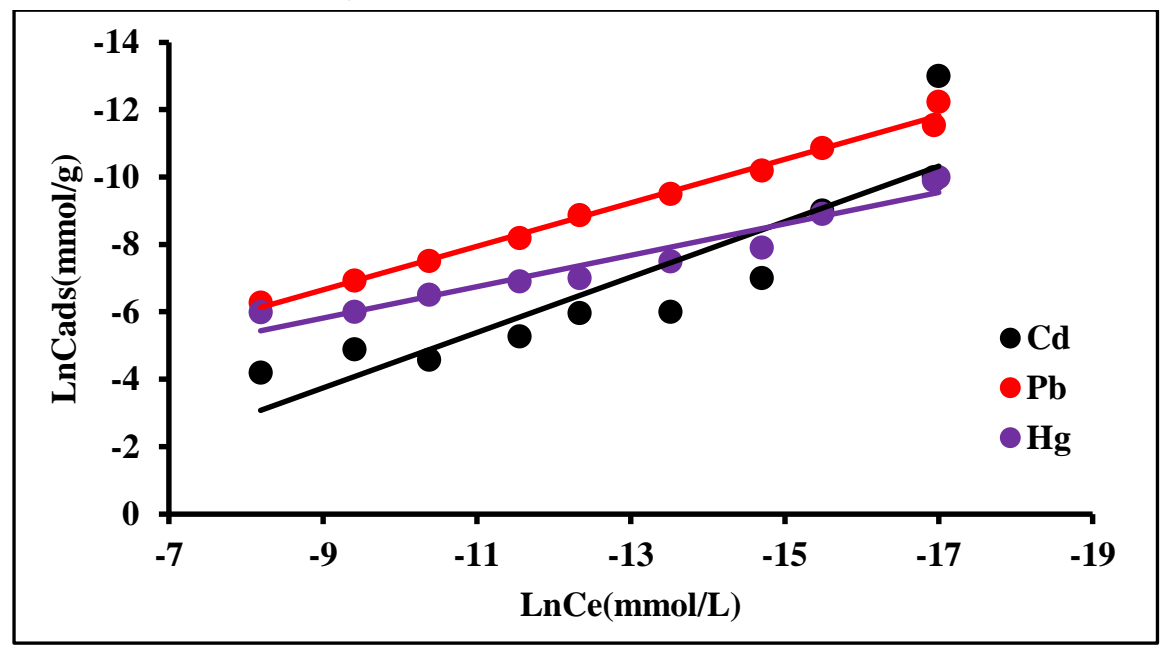

FIGURE 8 Freundlich isotherm (Conc. $2.5 \times 10^{-5}$ to $2.5 \times 10^{-7} \mathrm{~mol} / \mathrm{L}$ ), $0.1 \mathrm{~g}$ of DFCS resin per $10 \mathrm{~mL}$ of metal solution at $25^{\circ} \mathrm{C}$ 
TABLE 2 Fruendlich isotherm parameters

\begin{tabular}{cccc}
\hline Metal & $\mathbf{A}\left(\mathbf{m g ~ g}^{-\mathbf{1}}\right)$ & $\mathbf{n}$ & $\mathbf{R}^{\mathbf{2}}$ \\
\hline $\mathbf{C d}^{2+}$ & 0.704 & 1.37 & 0.992 \\
$\mathbf{P b}^{2+}$ & 0.748 & 1.35 & 0.997 \\
$\mathbf{H g}^{2+}$ & 0.7033 & 1.51 & 0.990 \\
\hline
\end{tabular}

Dubinin-Radushkevich adsorption isotherm model describes the nature of adsorption and estimate the energy utilized during adsorption process. D-R model constant values can be calculated using the Equation 6. While the Polanyi potential can be described well by utilizing the Equation 7 while the $E(\mathrm{~kJ} / \mathrm{mol})$ values can be calculated by Equation 8 .

$$
\begin{aligned}
& \ln C_{a d s}=\ln X_{m}-\beta \varepsilon^{2} \\
& \varepsilon=R T \ln \left(1+\frac{1}{C_{e}}\right)
\end{aligned}
$$

$$
E=\frac{1}{\sqrt{-2 \beta}}
$$

Where $R$ is the gas constant, $T$ is the temperature in Kelvin, and $X_{m}$ is the adsorption capacity.

The graph has been plotted between Polanyi potential value vs $\ln \mathrm{C}_{a d s}$ (mmol.g-1) which shows linear regression of metal ions on DFCS resin shown in (Figure 9). The constant values of this model are enlisted in Table 3.

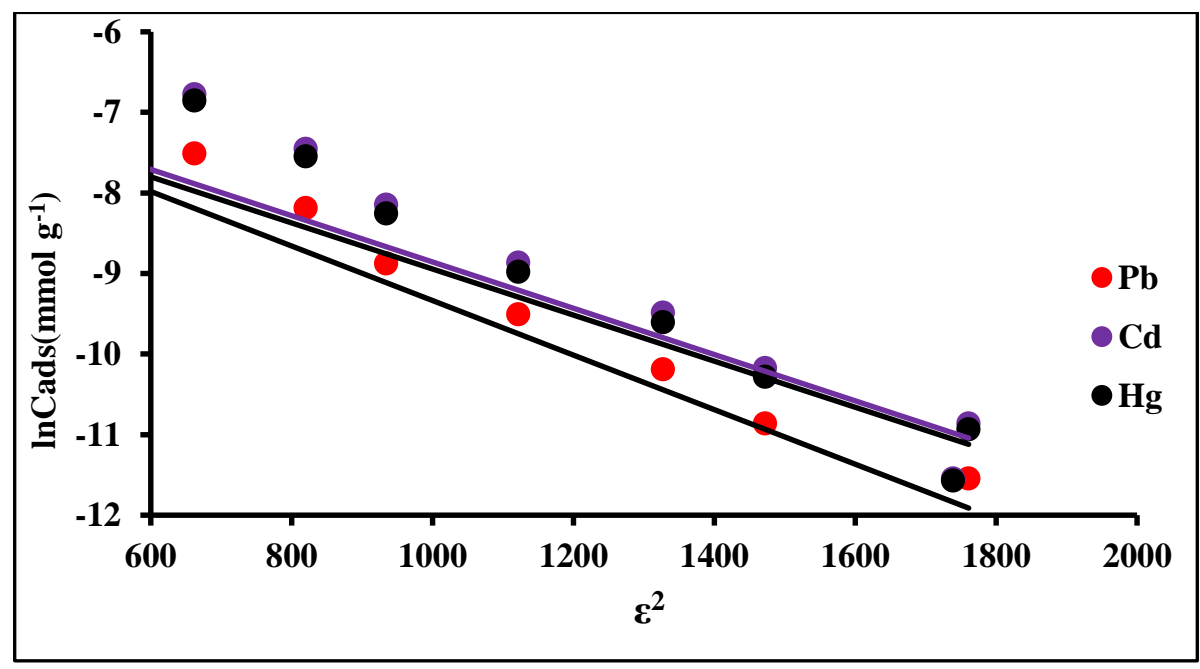

FIGURE 9 D-R isotherm (Conc. $2.5 \times 10^{-5}$ to $2.5 \times 10^{-7} \mathrm{~mol} / \mathrm{L}$ ), $0.1 \mathrm{~g}$ DFCS resin per $10 \mathrm{~mL}$ of metal ions at $25^{\circ} \mathrm{C}$ )

The adsorption capacity $\left(X_{m}\right)$ was calculated as $6.95,8.56$ and $9.80 \mathrm{mmol} / \mathrm{g}$ and $(E)$ was found to be $10.7,10.9$ and $10.8 \mathrm{~kJ} / \mathrm{mol}$ for the $\mathrm{Cd}^{2+}, \mathrm{Pb}^{2+}$ and $\mathrm{Hg}^{2+}$, respectively. The $E$ value is between 9.0 and $16.0 \mathrm{~kJ} / \mathrm{mol}$, suggesting that the metal ions are adsorbed onto DFCS resin mainly by ion exchange mechanism and is chemisorption in nature.

TABLE 3 D-R adsorption isotherm parameters

\begin{tabular}{cccc}
\hline Metals & $\mathbf{X}_{\mathbf{m}}(\mathbf{m m o l} / \mathbf{g})$ & $\mathbf{E}(\mathbf{k J} / \mathbf{~ m o l})$ & $\mathbf{R}^{\mathbf{2}}$ \\
\hline $\mathbf{C d}^{2+}$ & 6.95 & 10.7 & 0.991 \\
$\mathbf{P b}^{2+}$ & 8.56 & 10.9 & 0.990 \\
$\mathbf{H g}^{2+}$ & 9.80 & 10.8 & 0.993 \\
\hline
\end{tabular}




\section{Thermodynamics studies}

Adsorption of metal ion on the DFCS resin was analyzed at various temperatures and it is noticed that the $\%$ adsorption increases with raise in temperature (Figure 9). Therefore, the graph has been plotted between $\operatorname{lnk}_{c}$ versus $1 / \mathrm{T}$ (Figure 10). Form the graph, $\Delta \mathrm{H}(\mathrm{KJ} / \mathrm{mol})$, $\Delta \mathrm{S}(\mathrm{KJ} / \mathrm{mol} / \mathrm{K})$ and listed in Table 4 , which describes the thermodynamic phenomenon of adsorption process. The $(-\Delta G)$ values indicates the feasibility and spontaneity of adsorption process at higher temperature. The small and negative $(-\Delta \mathrm{H})$ values shows the adsorption process takes place exothermally and very low values of $\Delta S$ describes the good affinity of metal ions towards DFCS resin.

$$
\begin{aligned}
& \ln k_{c}=\frac{-\Delta H}{R T}+\frac{\Delta S}{R} \\
& \Delta G=-R T \ln k_{c}
\end{aligned}
$$

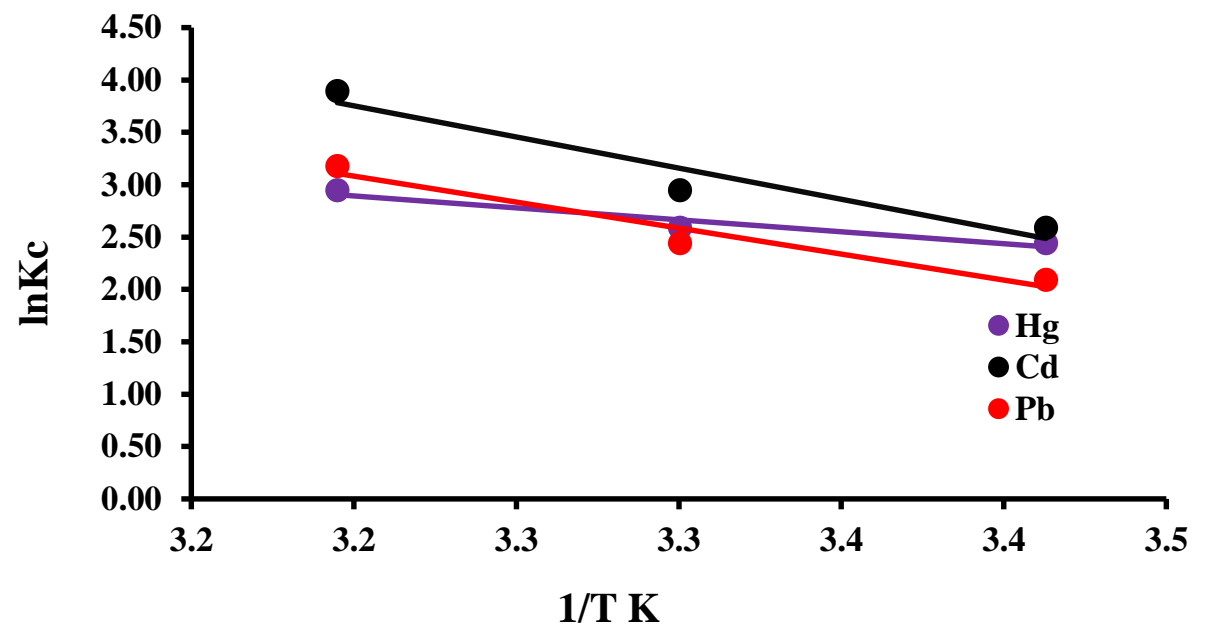

FIGURE 10 Graph of $\operatorname{lnKc}$ vs $1 / \mathrm{T}$ for the Adsorption of $\mathrm{Cd}^{2+}, \mathrm{Pb}^{2+}$ and $\mathrm{Hg}^{2+}$ on DFCS resin.

TABLE 4 Thermodynamic parameters for adsorption of $\mathrm{Cd}^{2+}, \mathrm{Pb}^{2+}$ and $\mathrm{Hg}^{2+}$ on DFCS resin

\begin{tabular}{cccccc} 
Metal & $\boldsymbol{\Delta H}$ & $\boldsymbol{\Delta S}$ & Temperature & $\boldsymbol{\Delta G}$ & InKc \\
\hline \multirow{3}{*}{$\mathbf{H g}^{2+}$} & & & 293 & -5.9 & 2.4 \\
& -0.01 & 0.08 & 303 & -6.5 & 2.6 \\
& & & 313 & -7.6 & 2.9 \\
$\mathbf{P b}^{2+}$ & \multirow{3}{*}{0.04} & \multirow{2}{*}{0.16} & 293 & -5.6 & 2.3 \\
& & & 303 & -5.0 & 2.0 \\
& & & 313 & -6.1 & 2.4 \\
$\mathbf{C d}^{2+}$ & -0.04 & 0.19 & 293 & -7.3 & 2.9 \\
& & & 303 & -8.4 & 3.1 \\
& & & 313 & -10.1 & 3.8 \\
\hline
\end{tabular}

\section{Adsorption kinetic}

The adsorption percentage of the $\mathrm{Cd}^{2+}, \mathrm{Pb}^{2+}$, and $\mathrm{Hg}^{2+}$ by DFCS resin is affected by the temperature and time which is shown in Figure 11 . The $\%$ adsorption increased with raising the reaction temperature and time as the metal ions in solution travel faster at high temperature and remains in contact with the passage of time. The kinetic study for the adsorption of the $\mathrm{Cd}^{2+}, \mathrm{Pb}^{2+}$, and $\mathrm{Hg}^{2+}$ metal ions on the DFCS resin were performed and the experimental data was subjected to the pseudo first order and pseudo second order kinetic equations. The kinetic parameters along with the correlation coefficient are 
presented in Table 5. The values of the correlation coefficient for both the kinetic models were plotted at different temperatures. The values of the correlation coefficient of the pseudo first order kinetic model are less than that of pseudo second order kinetic model; therefore, the adsorption follows the pseudo second order kinetic model. Therefore, it is assuming that during the adsorption process rate determining step is physio sorption in nature that governed by weak forces of attraction in between adsorbent surface and metal ions. The $\mathrm{Pb}^{2+}$ $\mathrm{Hg}^{2+}$ and $\mathrm{Cd}^{2+}$ adsorption on DFCS resin at 298$313 \mathrm{~K}$ can be well described by pseudo second order kinetic equation. The values are tabulated in Table 5.

TABLE 5 Pseudo $1^{\text {st }}$ and $2^{\text {nd }}$ order kinetic parameters $\mathrm{Cd}^{2+}, \mathrm{Pb}^{2+}$ and $\mathrm{Hg}^{2+}$ at different temperatures

\begin{tabular}{|c|c|c|c|c|c|c|}
\hline \multirow{2}{*}{$\begin{array}{c}\text { Temperature } \\
\mathbf{P b}^{2+}\end{array}$} & \multicolumn{3}{|c|}{ Pseudo First Order Kinetic Model } & \multicolumn{3}{|c|}{$\begin{array}{c}\text { Pseudo Second Order Kinetic } \\
\text { Model }\end{array}$} \\
\hline & $\mathrm{K}_{1} \mathbf{m i n}^{-1}$ & $\begin{array}{c}\mathrm{qe} \\
(\mathrm{mmol} / \mathrm{g})\end{array}$ & $R^{2}$ & $\begin{array}{c}\mathrm{K}_{2} \mathrm{~g} \mathrm{~mol}^{-} \\
\text {mint }^{-1}\end{array}$ & $\begin{array}{c}\mathrm{qe} \\
(\mathrm{mol} / \mathrm{g})\end{array}$ & $R^{2}$ \\
\hline 293 & 0.013 & 213.9 & 0.246 & 197.4 & 0.00154 & 0.9910 \\
\hline 303 & 0.0006 & 77.58 & 0.176 & 209 & 0.00023 & 0.9665 \\
\hline 313 & 0.0006 & 8.178 & 0.245 & 2242 & 0.00167 & 0.9997 \\
\hline \multicolumn{7}{|l|}{$\mathrm{Hg}^{2+}$} \\
\hline 293 & 0.0013 & 212.7 & 0.248 & 143.7 & 0.00183 & 0.994 \\
\hline 303 & 0.0006 & 75.43 & 0.1391 & 162.9 & 0.00030 & 0.999 \\
\hline 313 & 0.0006 & 7.830 & 0.1442 & 40060 & 0.0027 & 0.994 \\
\hline \multicolumn{7}{|l|}{$\mathrm{Cd}^{2+}$} \\
\hline 293 & 0.0127 & 218.4 & 0.24 & 184.76 & 0.001472 & 0.990 \\
\hline 303 & 0.0007 & 78.3 & 0.24 & 212.27 & 0.000235 & 0.966 \\
\hline 313 & 0.0008 & 8.10 & 0.14 & 395.90 & 0.002563 & 0.996 \\
\hline
\end{tabular}

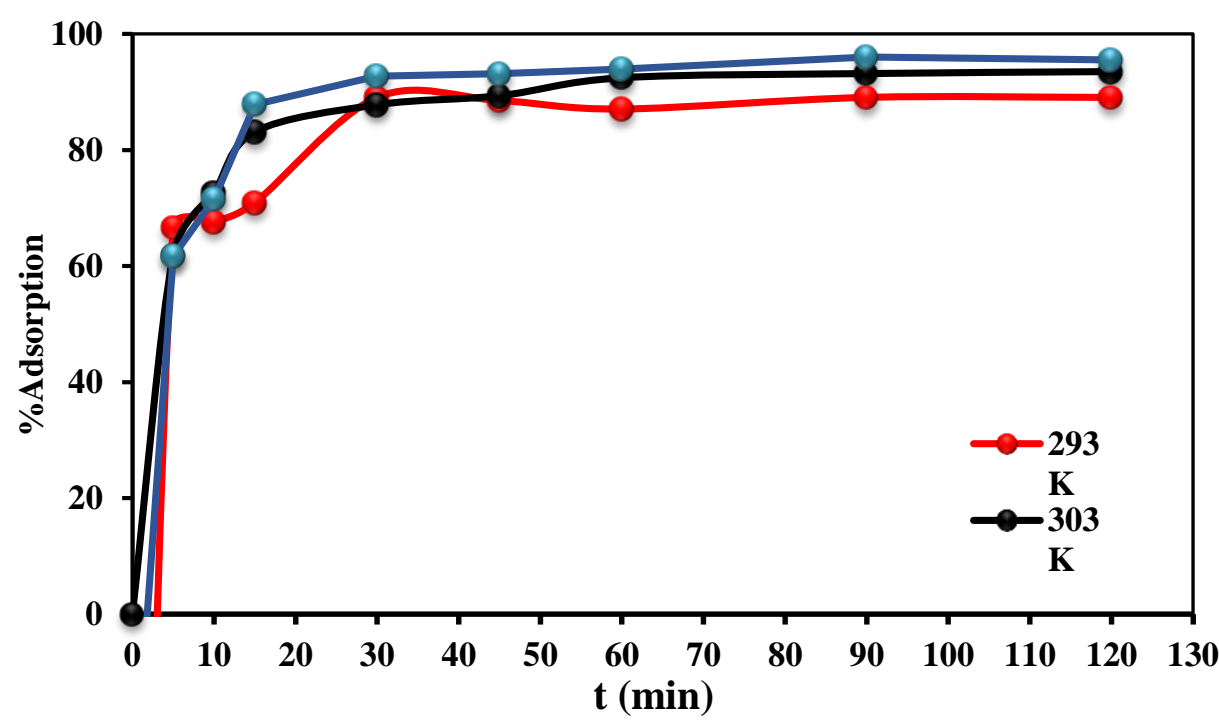

FIGURE 11 Effect of time and temperature on the removal of $\mathrm{Cd}^{2+}, \mathrm{Pb}^{2+}$ and $\mathrm{Hg}^{2+}$ metal ion

\section{Comparative study}

The present study shows the maximum adsorption percentage of $\mathrm{Cd}^{2+}, \mathrm{Pd}^{2+}$ and $\mathrm{Hg}^{2+}$.
As seen in Table 6, different studies were compared with the current study. 
TABLE 6 Comparison of DFCS resin with other adsorbents for $\mathrm{Cd}^{2+}, \mathrm{Pb}^{2+}$ and $\mathrm{Hg}^{2+}$

\begin{tabular}{cccc}
\hline Adsorbent & Metal ion & \% Adsorption & Reference \\
\hline Magnetic composite & $\mathrm{Cu}, \mathrm{Mn}, \mathrm{Cd}, \mathrm{Pb}$ & $90-95$ & {$[30]$} \\
CoFe2O4-SiO2 (CF-S) & $\mathrm{Pb}, \mathrm{Cu}, \mathrm{Ag}, \mathrm{Zn}$ and & $95-99$ & {$[31]$} \\
Fe-Mg (hydroxide)@GO & $\mathrm{Cu}$ & & \\
Graphene oxide-calcium-zinc & $\mathrm{Cr}(\mathrm{III})$ and Cu(II) & $96-97$ & {$[32]$} \\
(GO@CZ) Nanocomposite & $\mathrm{Hg}, \mathrm{As}$ & 80 & {$[33]$} \\
Muscovite/phillipsitic zeolite & $\mathrm{Pb}^{2+}$ & 90 & {$[34]$} \\
NiFe204 coated sand & $\mathrm{Cd}, \mathrm{Pb}$ & $95-99$ & $\begin{array}{c}\text { Present } \\
\text { study }\end{array}$ \\
DFCS resin & and Hg & & \\
\hline
\end{tabular}

\section{Conclusion}

This study highlights the synthesis of $p$ diethylamine functionalized calix[4]arene silica (DFCS) resin for the effective removal of $\mathrm{Cd}^{2+}, \mathrm{Pb}^{2+}$ and $\mathrm{Hg}^{2+}$ from water. The batch adsorption studies were conducted to examine the ability of the DFCS resin for metal ion removal. The results demonstrate that the DFCS resin had a very good efficiency for the removal of these toxic ions under the optimized conditions. To validate the adsorption phenomenon, the isotherm models were applied and Freundlich model was found to be the best fit with good correlation coefficient values ( $\left.R^{2} 0.99\right)$, which reveals that the resin has good multilayer adsorption capacity. Thermodynamic parameters such as $\Delta \mathrm{H}(\mathrm{KJ} / \mathrm{mol}), \Delta \mathrm{S}(\mathrm{KJ} / \mathrm{mol} / \mathrm{K})$ and $(-\Delta \mathrm{G})$ describe that the adsorption is spontaneous and exothermic in nature and kinetic study helped to determine adsorption mechanism. The study may find its applicability in the fields of analytical and environmental sciences.

\section{Acknowledgements}

We are thankful to National Center of Excellence in Analytical Chemistry University of Sindh Jamshoro, Sindh-Pakistan, for his kind support and providing me environment for my research.

\section{Orcid:}

Ranjhan Junejo: https://orcid.org/0000-00020090-1146

\section{References}

[1] M.A. Kamboh, W.A. Wan Ibrahim, H. Rashidi Nodeh, L.A. Zardari, M.M. Sanagi, Environ. Technol., 2019, 40, 2482-2493.

[2] M.M. Sihabudeen, A.A. Ali, A.Z. Hussain, Int. J. Chemtech Res., 2016, 9, 254-257.

[3] C.V. Mohod, J. Dhote, Int. J. Innov. Res. Sci. Eng. Technol., 2013, 2, 2992-2996.

[4] H. Alyahya, A.H. El-Gendy, S. Al Farraj, M. El-Hedeny, Water, Air, \& Soil Pollution, 2011, 214, 499-507.

[5] R. Goyer, Issue paper on the human health effects of metals. Editor, US EPA, 2004.

[6] L. Järup, British medical bulletin, 2003, 68, 167-182.

[7] U. Lindh, Ambio, 2007, 36, 107-110.

[8] S.A. El-Safty, D. Prabhakaran, A.A. Ismail, H. Matsunaga, F. Mizukami, Adv. Funct. Mater., 2007, 17, 3731-3745.

[9] J. Ayenimo, A. Yusuf, A. Adekunle, 0. Makinde, Bull. Environ. Contam. Toxicol., 2010, 84, 8-14.

[10] G. Mebrahtu, S. Zerabruk, Momona Ethiop. J. Sci 2011, 3, 105-121.

[11] Z.B. Mokhtari-Hosseini, E. Kazemiyan, R. Tayebee, T. Shenavaei-Zare, Hemijska Industrija, 2016, 70, 21-29.

[12] R. Tayebee, J. Water Environ. Nanotechnol, 2018, 3, 40-50. 
[13] R. Jalilian, A. Taheri, E-polymers, 2018, 18, 123-134.

[14] A. Alkherraz, O. Hashad, K. Elsherif, Prog. Chem. Biochem. Res., 2019, 2, 99-107.

[15] K. Trivunac, S. Stevanovic, Chemosphere, 2006, 64, 486-491.

[16] R. Junejo, S. Memon, F.N. Memon, A.A. Memon, F. Durmaz, A.A. Bhatti, A.A. Bhatti, J. Chem. Eng. Data, 2019, 64, 3407-3415.

[17] I.B. Solangi, S. Memon, M. Bhanger, Anal. Chim. Acta., 2009, 638, 146-153.

[18] I.B. Solangi, S. Memon, N. Memon, M. Bhanger, J. Macromol. Sci. A., 2008, 45, 10031008.

[19] A. Shah, T. Kazi, J. Baig, H. Afridi, G. Kandhro, M. Arain, N. Kolachi, S. Wadhwa, Food Chem. Toxicol, 2010, 48, 65-69.

[20] N. Pourreza, K. Ghanemi, J. Hazard. Mater, 2009, 161, 982-987.

[21] C.D. Gutsche, B. Dhawan, K.H. No, R. Muthukrishnan, J. Am. Chem. Soc., 1981, 103, 3782-3792.

[22] C.D. Gutsche, L.-G. Lin, Tetrahedron, 1986, 42, 1633-1640.

[23] C.D. Gutsche, M. Iqbal, Organic Syntheses, 2003, 68, 234-234.

[24] C.D. Gutsche, K.C. Nam, J. Am. Chem. Soc., 1988, 110, 6153-6162.

[25] R.A. Wuana, F.E. Okieimen, Isrn Ecology 2011, 2011, 1-20.
[26] M.-Z. Asfari, V. Böhmer, J. Harrowfield, J. Vicens, Calixarenes 2001. Springer Science \& Business Media, 2007, 1-683.

[27] C.D. Gutsche, M. Iqbal, D. Stewart, J. Org. Chem., 1986, 51, 742-745.

[28] C.D. Gutsche, L.-G. Lin, Tetrahedron, 1986, 42, 1633-1640.

[29] P.K. Jal, S. Patel, B.K. Mishra, Talanta, 2004, 62, 1005-1028.

[30] C. Ren, X. Ding, W. Li, H. Wu, H. Yang, J. Chem. Eng. Data, 2017, 62, 1865-1875.

[31] D. Huang, B. Li, M. Wu, S. Kuga, Y. Huang, J. Chem. Eng. Data, 2018, 63, 2097-2105.

[32] R. Sharma, D. Kumar, J. Chem. Eng. Data, 2018, 63, 4560-4572.

[33] M.A. Salam, M.R. Abukhadra, M. Mostafa, Environ. Sci. Pollut. Res., 2020, 27, 1324713260.

[34] E. Fereydoun Asl, F.S. Mohseni-Shahri, F. Moeinpour, Eurasian Chem. Commun., 2019, 1, 480-493.

How to cite this article: Ranjhan Junejo*, Shahabuddin Memon, Ismail Murat Palabiyik. Efficient adsorption of heavy metal ions onto diethylamine functionalized calix[4] arene based silica resin. Eurasian Chemical Communications, 2020, 2(7), 785-797. Link:

http://www.echemcom.com/article_106 234.html

Copyright ( 22020 by SPC (Sami Publishing Company)+ is an open access article distributed under the Creative Commons Attribution License, which permits unrestricted use, distribution, and reproduction in any medium, provided the original work is properly cited. 